\title{
Foetal and neonatal development of luteinising hormone and its regulatory systems in the pig
}

\author{
N. Parvizi \\ Department of Functional Genomics and Bioregulation, Institute of Animal Science Mariensee, Federal \\ Agricultural Research Centre (FAL), 31535 Neustadt, Germany
}

\begin{abstract}
This review is a short summary of the "state-of-the-art" regarding the ontogeny of $\mathrm{LH}$ and part of its control system in the pig. The maturity of pituitary gonadotropin cells and the vascular drainage between the hypothalamus and pituitary are probably the most important steps in the developmental process of gonadotropin (LH) secretion. In the pig, these are achieved at around day 80 of foetal age, when LH cell density is comparable to that observed in adults. The hypothalamus regulates foetal pituitary LH secretion via LHRH well ahead of parturition. However, the main prerequisite of ovarian activity (ovulation), the "GnRH pulse generator", is not ready to function in the foetus. Pulsatile LH release is inducible by treatment of the foetal pituitary with $\mathrm{LHRH}$, but extrahypothalamic modulating systems are not fully functioning until after birth. Likewise, there is no gonadal steroid feedback control of pituitary $\mathrm{LH}$ secretion up to the second week of neonatal age.
\end{abstract}

\section{Introduction}

The study of ontogenetic development of reproduction was, for decades, dominated by, and to a great extent, limited to research involving gonadal growth and onset of placental and gonadal hormone release. Gradually the emphasis was placed on sexual differentiation. This was followed by concentrated research on pituitary cell differentiation and central nervous system control of gonadotropin secretion during the foetal and neonatal periods. To date, most immunohistochemical work has been confirmed utilizing methods of molecular genetics. The latter have been helpful tools to further elucidate fine adjustments within the system.

Onset of pituitary function as well as control of the pituitary by the brain is dependent on adequate development of hypothalamic nuclei, and their afferent and efferent connections within and outside the hypothalamus, on development of the vascular drainage from the hypothalamus to the pituitary and on maturation of pituitary gonadotropin cells. This review is a short survey of the "state-of-the-art" regarding the ontogeny of LH secretion and part of its regulatory system in the pig.

e-mail: parvizi@tzv.fal.de

Corresponding address: Prof. Dr. N. Parvizi, Department of Functional Genomics and Bioregulation, Institute of Animal Science, Höltystrasse 10, 31535 Neustadt, Germany 


\section{LH and LHRH producing cells}

Rathke's pouch appears around embryonic day 20. Pituitary growth is rather slow until day 60 post coitus (pc), when pituitaries weigh only $2.5 \mathrm{mg}$ (Figure 1). They double in weight between day $60 \mathrm{pc}$ and day $80 \mathrm{pc}$ and are 5- to 6-fold heavier between day 80 and $105 \mathrm{pc}$ than those at day $60 \mathrm{pc}$. The capillary loops in the median eminence are first visible at day $60 \mathrm{pc}$.
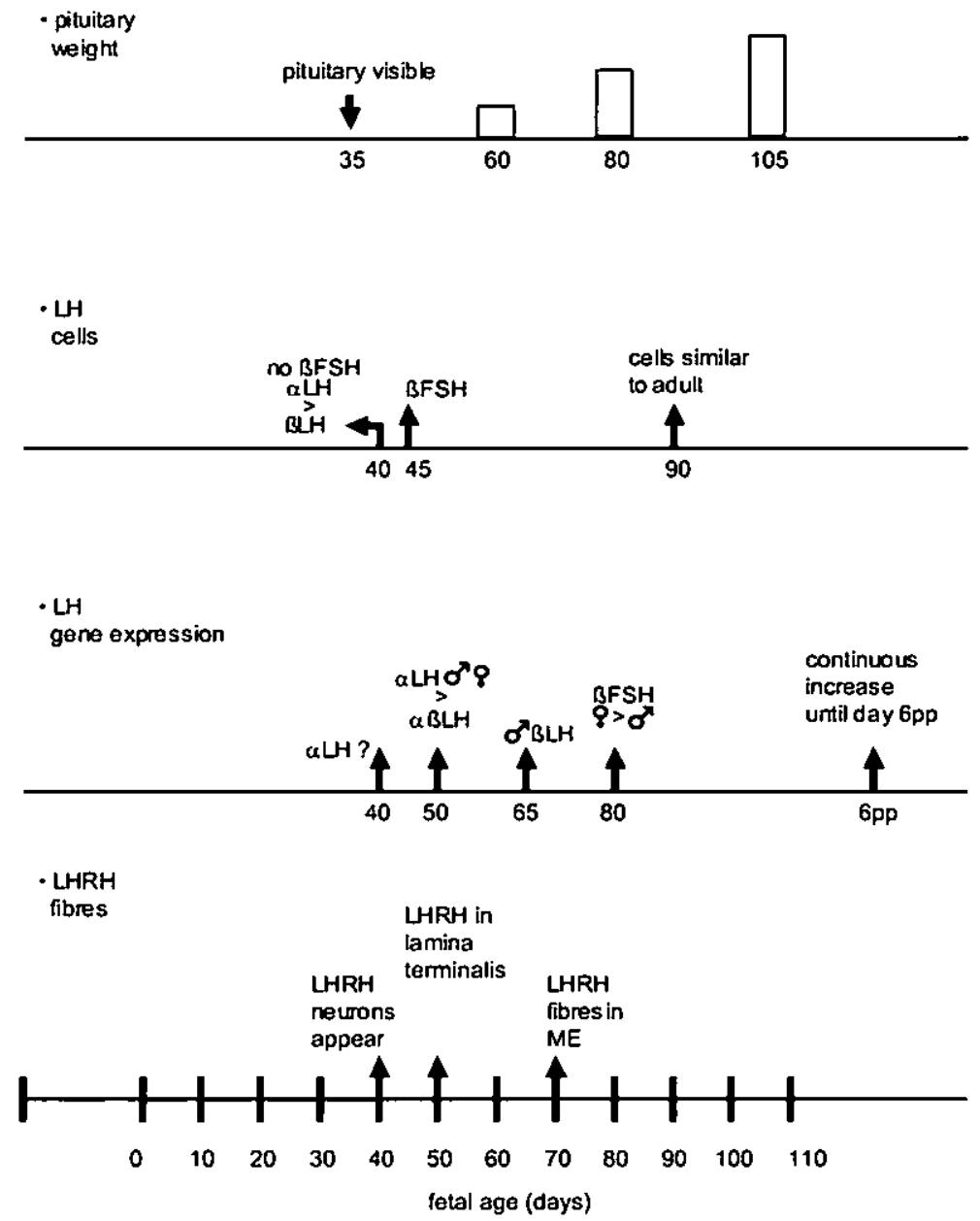

$p p=$ days postpartum; $M E=$ median eminence

Figure 1. Ontogeny of brain-pituitary relations

Individual, scattered LHRH perikarya were detectable in the paraolfactory and rostral precommissural area on day $40 \mathrm{pc}$ (Danchin and Dubois, 1982). Immunoreactive LH, indicative of LH cells, was also present from day 40 onwards (Dacheux and Martinat, 1983; Sasaki et al., 1992), and around day $80 \mathrm{pc}$, cell densities were comparable to those of adults (Dacheux, 1984). Based on histochemical techniques, the density of $\mathrm{LH}$. cells, relative to the glandular mass of the anterior part of the pituitary gland, was $0.12 \%$ on day $50 \mathrm{pc}$ and $0.61 \%$ on day $90 \mathrm{pc}$. This volume increased sharply to $4.5 \%$ between day 90 and $100 \mathrm{pc}$ (Meijer et al., 1985). Furthermore, a regulatory action of LHRH on pituitary gonadotropin cell development probably begins around day $70 \mathrm{pc}$. 
Visualization of $\mathrm{LH}$ and $\mathrm{FSH}$ peptides by immunohistochemistry as well as monitoring of $\mathrm{LH}$ and FSH gene expression by in situ-hybridisation indicated that the $\alpha$-subunit is present before the ß- subunits, and LH precedes FSH. The first signals for both LH- $B$ and FSH-ß subunits were clearly located in the area close to the intermediate lobe (Ma et al., 1996). More recent studies, utilizing the northern blot technique to quantify development of $\mathrm{LH}$ and $\mathrm{FSH}$ mRNA, confirmed that ontogeny of the foetal pituitary is characterised by a marked increase in LH-ß mRNA from day 50 pc until day $110 \mathrm{pc}$ in female foetuses (Fig. 2) while the increase during this period is less obvious in male foetuses (Granz et al., 1997). It is appropriate to note that the LH receptor peptide and LH receptor gene-expression were present as early as day $30 \mathrm{pc}$ in both ovarian and testicular tissue (Goxe et al., 1993; Derecka et al., 1999). However, neither immunohistochemical nor in situ hybridisation nor northern blot hybridisation studies could prove that $\mathrm{LH}$ production started in the pituitary before day 40-50 pc (Dacheux, 1984; Ma et al., 1996; Granz et al., 1997).
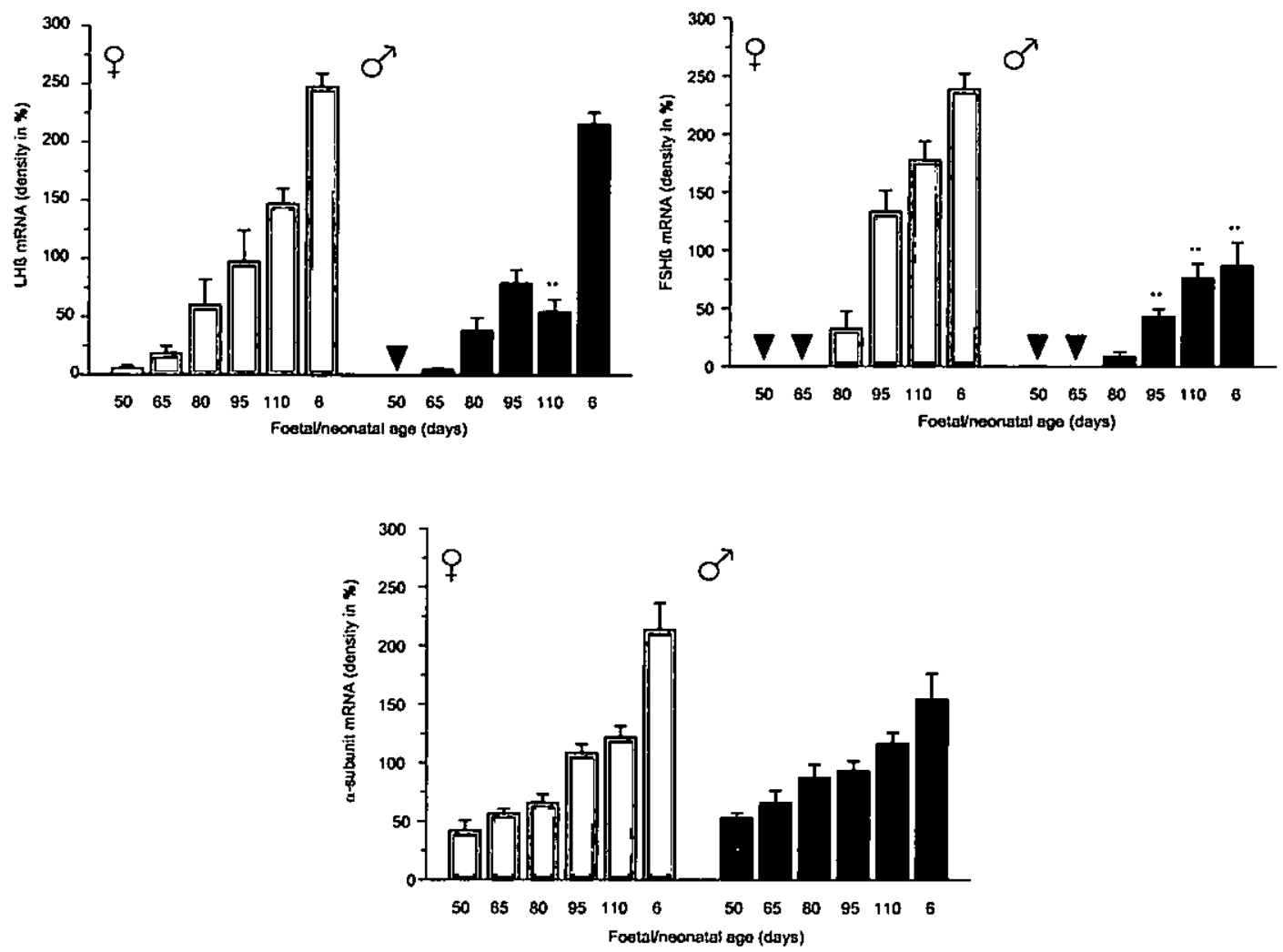

Figure 2. Levels of LH- $\beta$ mRNA, FSH- $\beta$ mRNA and $\alpha$-subunit mRNA in male and female foetal (day 5 to 110 ) and neonatal (day 6 ) pigs. $\boldsymbol{\nabla}$ - not detectable; ${ }^{* *}-\mathrm{P} \leq 0.05$ male vs. female (Data adapted from Granz et al., 1997).

Neuronatin, a peptide consisting of an $\alpha$ - and $\beta$-form, with 81 and 54 amino acids, respectively, was originally found to be expressed during hind brain, Rathke's pouch and adenohypophysial development in the rat and human (Joseph et al., 1994, 1995; Wijnholdeset al., 1995; Usui et al., 1997). Its expression declined in adulthood, thus neuronatin is most likely involved in brain and pituitary development (Dou and Joseph, 1998). Strong support for this postulation 
comes from results showing that neuronatin is under control of the pituitary transcription factor gene, prop i, in mice (Sornson et al., 1996). Both forms of neuronatin were expressed at day 40 pc in the foetal pig pituitary. The density of expression remained constant throughout foetal life, but increased up to 2-fold shortly after birth. B-neuronatin seems to be the dominant form in foetuses. However, around day 8 post partum (pp), expression of the $\alpha$-form exceeded that of the B-form (Aikawa et al., 2003).

\section{LH secretion}

In foetal pigs, circulating levels of LH were detectable as early as day $60 \mathrm{pc}$ (Fig. 2). Plasma LH levels doubled between day 60 and $80 \mathrm{pc}$, and increased further until day $110 \mathrm{pc}$ (Bruhn et al., 1983; Behrens-Herrler and Parvizi, 1993). This developmental secretory pattern follows LH- $B$ subunit gene expression in the pituitary (Fig. 3).
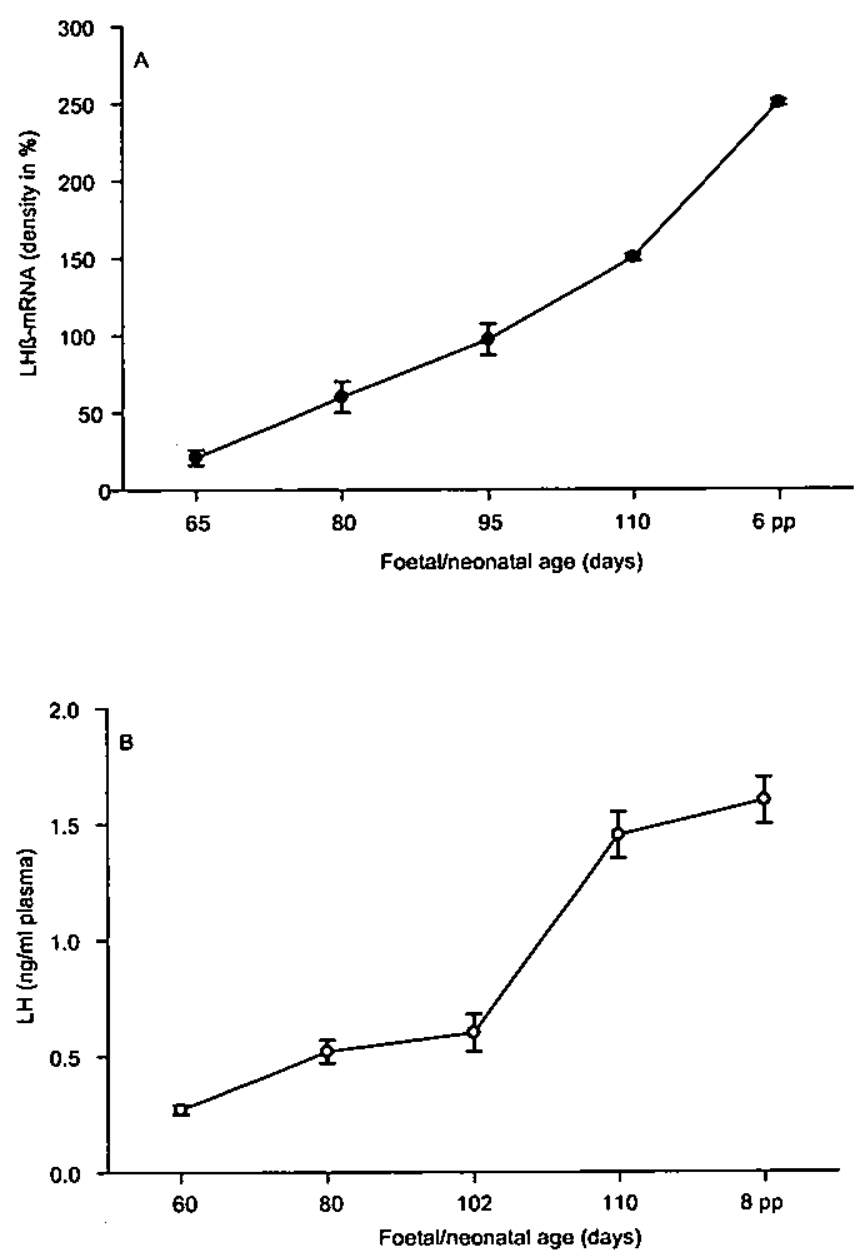

Figure 3. Foetal (day 60 to 110 ) and neonatal (day 6 or 8 ) levels of L.H-B mRNA (A) and plasma LH concentrations (B) (Data adapted from Ponzillius et al., 1986 and Granz et al., 1997). 
Apparently, there is a slight sex difference in the concentration of plasma LH towards the end of gestation. Plasma LH levels were higher in female foetuses than in males when single samples were withdrawn under so called acute experimental conditions (Colenbrander et al., 1977; Goxe et al., 1993). This difference could not be fully demonstrated using the chronically catheterised foetal pig model (Colenbrander et al., 1982; Ponzillius et al., 1986; Behrens-Herrler and Parvizi 1993). This controversy can be attributed to differences in experimental conditions and blood sampling procedures, or just to the method used for statistical verification of data; e.g. the difference in plasma $\mathrm{LH}$ values between male and female foetuses was $20 \%$ in the paper of Goxe et al. (1993) and $17-35 \%$ in the work published by Behrens-Herrler and Parvizi (1993). In general, plasma LH values measured in acute studies were higher in both female and male foetuses than LH levels obtained in chronically catheterised foetuses. On the other hand, the pituitary of female foetuses produces and stores much larger amounts of LH than the male foetal pituitary (Elsaesser et al., 1988; Granz et al., 1997). This deposit was easily released when pituitary cells were cultured in vitro (Elsaesser et al., 1988). Acute experimental condition could also induce such a $\mathrm{LH}$ discharge.

Mechanisms controlling pulsatile release of $\mathrm{LH}$ are obviously not fully developed in the prenatal pig. The few individual pulses, which occurred between day 80 to $110 \mathrm{pc}$, disappeared entirely on day $113 \mathrm{pc}$ (gestation $=114 \pm 1$ days), but reappeared with a marked increase in frequency on day 4 postpartum ( $\mathrm{pp}$ ) (Ponzillius et al., 1983). Brain control of pituitary function starts when the prerequisites of releasable LHRH, LHRH fibres and capillary loops near the median eminence and infundibulum are established around days 70 to $80 \mathrm{pc}$. At this age, intravenous (iv) injections of LHRH, as well as electrical or electrochemical stimulation of the hypothalamus, resulted in an incremental increase in plasma $\mathrm{LH}$ concentrations. The response increased as foetuses got older (Colenbrander et al., 1982; Bruhn et al., 1983). Stimulation of extrahypothalamic brain areas, such as the amygdala and hippocampus, had no effect on foetal pig $\mathrm{LH}$ secretion. Hence, extrahypothalamic control of $\mathrm{LH}$ seems to develop at the end of foetal life or later. LH release was provoked in pituitary cell cultures obtained from 50 or 60 day-old female, but not male, foetuses by LHRH challenges (Elsaesser et al., 1988; Zeng et al., 2005). This LHRH effect was mimicked by CAMP and the adenylcyclase activator, forskolin, whereas the protein kinase $\mathrm{C}$ activator, ATP, enhanced $\mathrm{LH}$ secretion in both sexes. Similar treatments on day 80 pc evoked massive LH discharges in female and male foetuses (Zeng et al., 2005).

Development of pituitary gonadotropin cells has been assumed to be LHRH independent. However, during the late foetal stage, from day $70 \mathrm{pc}$ onwards, exogenous LHRH disturbed the normal development of gonadotropic cells (Meijer et al., 1985).

\section{Gonadal steroid feedback}

The ability of foetal testes, but not foetal ovaries, to secrete steroids is very high at around days 32 to 36 of gestation (Raeside and Middleton, 1979; Ford et al., 1980). This corroborates data showing increased steroidogenic enzyme gene expression in testes of embryonic and foetal pigs (day $30 \mathrm{pc}$ ) (Conley et al., 1994). Testicular descent starts at around day 70 pc and is completed at around day $90 \mathrm{pc}$. Mean plasma testosterone levels are quite high before testicular descent. Testicular content of testosterone, as well as its metabolite, dihydrotestosterone, increased between day $60 \mathrm{pc}$ and $90 \mathrm{pc}$ (Visser and Heyns 1994). Sexual differentiation of the brain leading to the failure of males to produce LH surges comparable to those in the preovulatory stage of the oestrous cycle in females occurs around day $30 \mathrm{pc}$, a time of high testicular testosterone activity (Elsaesser and Parvizi, 1979; Petric et al., 2004). Both LH-ß gene expres- 
sion and plasma $\mathrm{LH}$ concentrations were attenuated in 80 day-old male foetuses when their mothers received testosterone at 30 days of gestation. Intrauterine testosterone treatments affected female foetuses on day $40 \mathrm{pc}$, while treatment of sows on gestational day 30 had no effect on LH-B mRNA or plasma LH levels in their female offspring (Fig. 4; Petric et al., 2004). Therefore, the critical period of sexual differentiation of the control of $\mathrm{LH}$ release seems to be situated between days 30 and 40 of gestation as previously suggested by Elsaesser and Parvizi (1979). Regardless of these effects of testosterone, foetal gonadectomy on day 105 pc had no effect on LH secretion (Fig. $5 \mathrm{~A}$ ) for up to 4 days thereafter (Ponzilius et al., 1986). In the male foetus, castration led to a significant reduction in circulating testosterone levels. Yet, there were no changes in plasma progesterone or $17-\beta$ oestradiol concentrations (Fig. $5 \mathrm{~A}$ ) after gonadectomy in female or male foetuses at day $105 \mathrm{pc}$ (Ponzillius et al., 1986). This supports the proposal of a non-gonadal origin for these prenatal steroids. Interestingly, ovariectomy of 4 day-old neonates also failed to alter circulating levels of these steroids (Fig. $5 \mathrm{~B}$ ), indicating that the pig ovary is quiescent at this age. The absence of gonadal steroid feedback on LH secretion in late stages of foetal life was also shown in experiments in which chronically catheterised foetuses were treated with oestradiol. In these studies (Parvizi, 1986), iv injections of 17 B-oestradiol had no effect on LH secretion in male or female foetuses on day 105 to 108 of gestation while administration of 2-hydroxy-oestradiol, a catecholoestrogen, resulted in a rapid decline in plasma LH levels. A non-oestrogenic action of 2-hydroxy-oestradiol on LH secretion may explain differences in the $\mathrm{LH}$ response to these two steroids. Several possible pathways for a non-oestrogenic action of catecholoestrogen include: a) interfering with metabolism of catecholamines by competition with catecholamines for catechol-o-methyltransferase; b) inhibition of tyrosine hydroxylase, the rate limiting enzyme of catecholamine biosynthesis; and c) binding of catecholoestrogen to brain and pituitary dopamine and adrenoceptors (Paden et al., 1982). Catecholoestrogen, now known as a brain steroid, inhibited LH secretion when microinjected into the brain in neonates and adults (Parvizi and Ellendorff, 1975, 1980, 1983).

\section{Opioids and their actions}

Opioids have been postulated to be important regulators of neuronal growth (Hauser et al., 1989), therefore, one should anticipate their early appearance in the brain. The opioid peptide synthesizing system functions in the early stages of foetal life. Immunoreactive $\alpha$ - and B-endorphin was visible as early as day 30 to $34 \mathrm{pc}$ (Dacheux, 1984) and POMC-mRNA, visualised by in situ hybridisation, was present on day $30 \mathrm{pc}$ (Ma et al., 1994) in the primordial hypophysis. A POMC signal was measurable on day $40 \mathrm{pc}$ in the intermediate lobe of the hypophysis and in structures of the diencephalon, e.g. arcuate nucleus and medial nucleus of thalamus, and 10 days later the signal was extended to fasciculus tegmenti. POMC mRNA in the intermediate lobe increased during gestation and reached adult levels around day $80 \mathrm{pc}$ (Ma et al., 1994; Kineman et al., 1989). Northern blot analysis demonstrated a linear increase in both proenkephalin A (PENK A) and proenkephalin B (PENK B, prodynorphin) mRNA in the foetal hippocampus during development (Fig. $6 \mathrm{~A}$ ). However, the increase in mRNA coding for PENK $B$ in the hippocampus occurred faster than mRNA coding for PENK $A$. In contrast, a maximum was observed in the striatum. PENK $A$ and $B$ mRNA levels continued to increase up to around mid-gestation and then declined (Pittius et al., 1987) and the ratio of PENK B mRNA to PENK A mRNA remained constant during foetal development.

Opioid binding sites were present in the brain at day 45 pc (Fig. 6 B), which is about 10 to 15 days after the appearance of opioid peptides in the brain. In the rat, a species which is less mature at birth, opioid receptors appeared in the brain by the second trimester of gestation (Kent et al., 

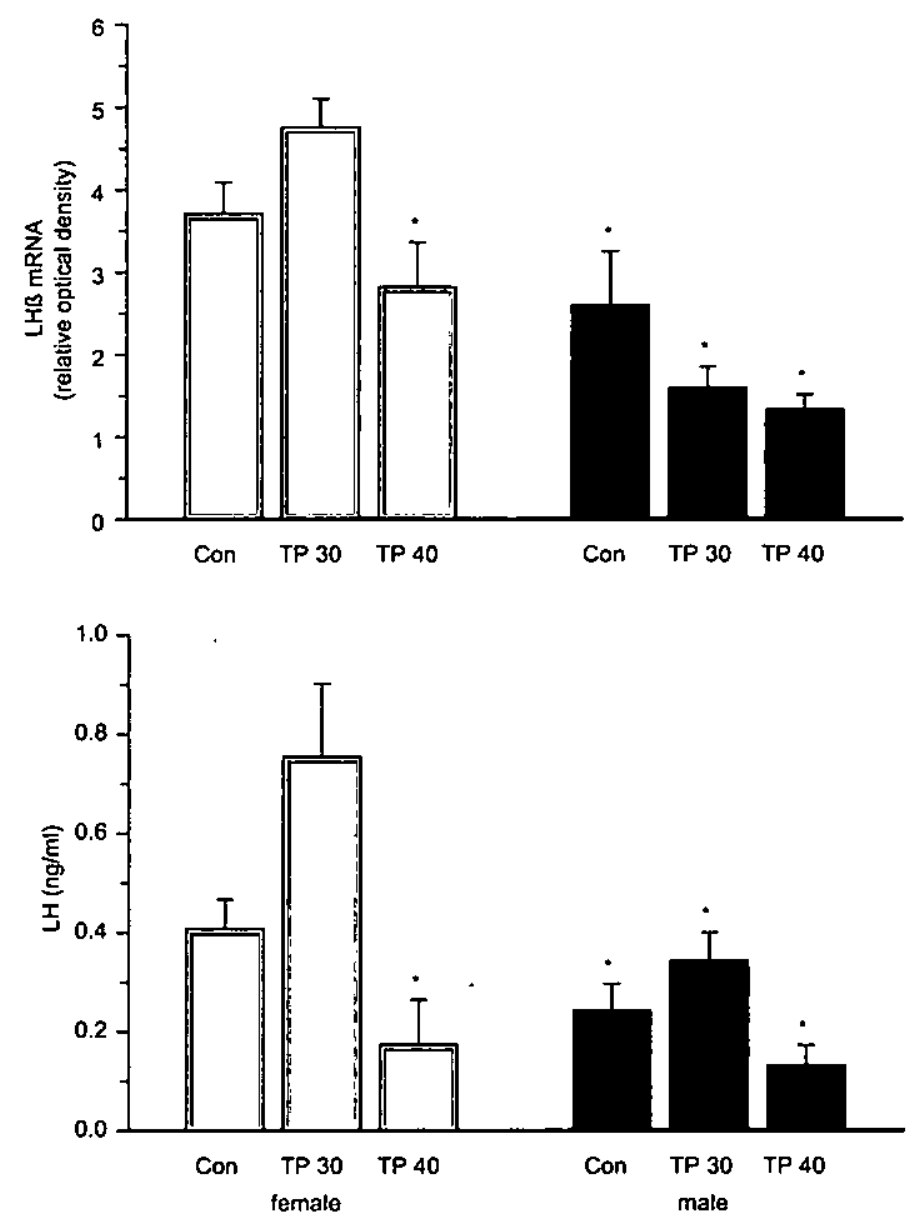

Figure 4. Contents of pituitary LH-ß mRNA and plasma LH concentrations in 80 day-old male and female foetuses. Mothers were treated three times at 2 day intervals with testosterone propionate (TP) starting at day 30 (TP30) or on day 40 (TP40) of gestation. * * different from TP30 female P $\leq 0.05$; con - control (data adapted from Petric et al., 2004).

1982), while opioid peptides first appeared in small amounts after birth (Bayon et al., 1989). Opioid binding sites increase during gestation, culminating in a sex difference around day $110 \mathrm{pC}$ (Fig. $6 \mathrm{~B}$ ). Opioid receptor concentrations, measured as B max of $\left[{ }^{3} \mathrm{H}\right]$-diprenorphine binding to brain tissue homogenates, decreased one day after birth and were comparable to those on day 90 pc with no sex difference (Fig. 6 B). A more detailed study of opioid receptors revealed that the sex difference in opioid receptor in whole brain homogenates was not reflected in specific brain areas, such as the striatum, hypothalamus, amygdala and hippocampus (Fig. 7). Another interesting, and to some extent, unexpected finding was that the delta-receptor type was apparently not fully developed in the foetus (Kahle, 1993). The mu-type seemed to be the predominant opioid receptor in the pig foetus (Fig. 7). Hence, the actions of opioids are most probably brought about by mu-receptors in the foetus. This is in contrast to the sheep foetus, in which delta and kappa receptors are the predominant ones (Yang and Chalis, 1991; Taylor et al., 1996). 

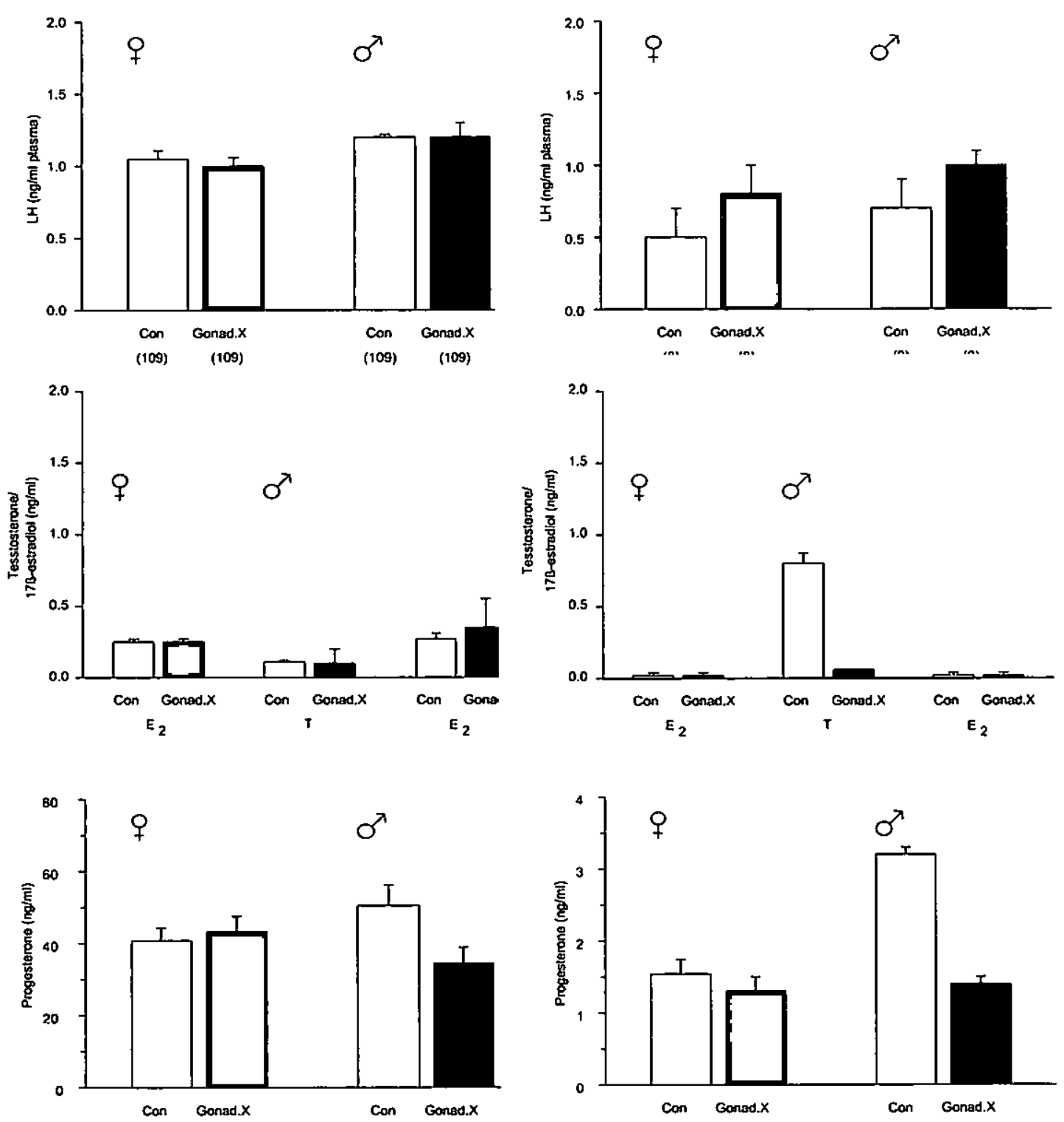

Figure 5. ( $A$ and $B$ ) Effects of gonadectomy (Gonad. $X$ ) on plasma $L H$, testosterone $(D, 17$ $B$ oestradiol $\left(E_{2}\right)$ and progesterone concentrations in male and female foetal (day $\left.109, A\right)$ and neonatal (day 8, B) pigs; con = control.

Daily iv treatments with morphine reduced LH release in female, but not male foetuses (Fig. 8). In the male foetus, attenuation of $\mathrm{LH}$ levels was induced by repeated iv applications of the opioid antagonist, naloxone (Fig. 8), whereas, single injections of naloxone had no effect (Behrens-Herrler and Parvizi, 1993). Several reasons have been postulated for the paradoxical long-term effects of naloxone (Dingledine et al., 1978; Cicero et al., 1989; Behrens-Herrler and Parvizi, 1993). Naloxone in low doses occasionally blocked auto-inhibition of opioid neurons at synapses (Rasmussen et al., 1988), which increased opioids, and thus, inhibited gonadotropin release. Also, under certain circumstances, naloxone does not act as a pure opioid antagonist. 

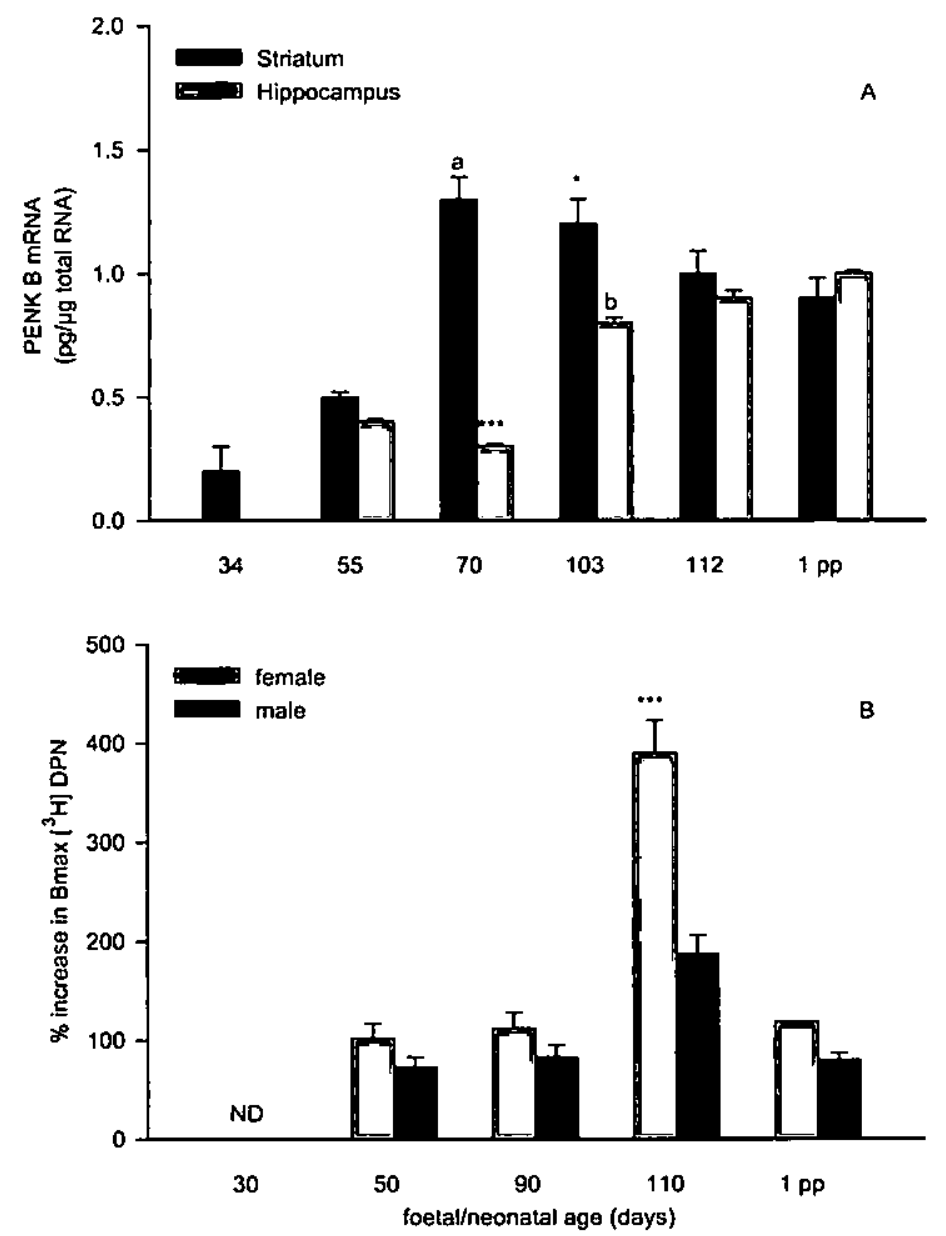

Figure 6. (A) Foetal (day 34 to 112) and neonatal (PP; day 1) ontogeny of proenkephalin B (PENK B; prodynorphin precursor) in striatum and hippocampus. For each tissue, four northern blots were scanned using a laser densitometer; solution hybridisation allowed determination of absolute PENK B mRNA levels. ${ }^{*}-\mathrm{P}<0.05$; $^{* * *}=\mathrm{P}<0.01$ striatum vs. hippocampus; $a=$ significantly $(P$ at least $=0.05$ ) different from all other values in striatum. $b$ significantly ( $P$ at least $=0.05$ ) different from preceding values; $34=$ whole brain. $(B)$ Development of the maximum binding capacity $\left(\mathrm{B}_{\max }\right)$ of ${ }^{3} \mathrm{H}$-diprenorphine (DPN) in foetal and neonatal pig brain. ${ }^{* * *} \mathrm{P}<0.01$ male vs. female; ND - not detectable.

Further, naloxone given chronically in the absence of opioids may act on sites other than opioid receptors (Grevel et al., 1985). Dingledine et al. (1978) demonstrated that naloxone acts as an antagonist when bound to gamma-amino butyric acid (GABA) receptors. Under most experimental conditions, GABA stimulated $\mathrm{LH}$ release, hence, blockade of GABA receptors by naloxone would lead to a decline in $\mathrm{LH}$ secretion. However, naloxone, in combination with morphine, acted as an opioid antagonist and abolished the long-term inhibitory effect of morphine on $\mathrm{LH}$ secretion in female foetuses (Fig. 8). Other foetal endocrine systems, such as the hypothalamo-pituitary-adrenal axis are much more sensitive to naloxone than the $\mathrm{LH}$ secretory system. Single iv injections of naloxone provoked a significant increase in foetal male and female plasma concentrations of cortisol ( $\mathrm{Li}$ and Parvizi, unpublished). 

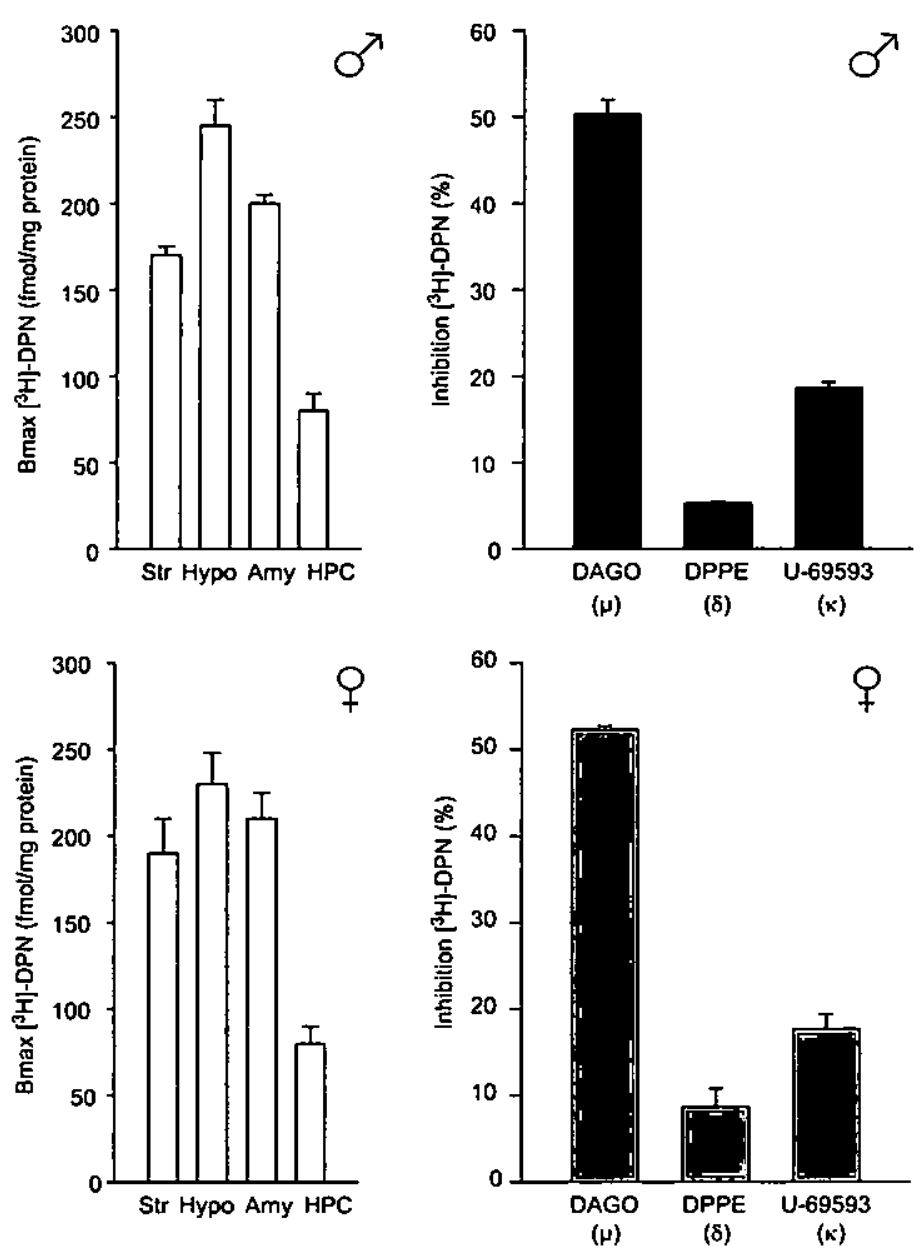

Figure 7. Left side: maximum binding capacity $\left(B_{\max }\right)$ of ${ }^{3} \mathrm{H}$-diprenorphine (DPN) in different brain areas of male and female pig foetuses (day 110). Str. - striatum; hypo - hypothalamus; amy = amygdala; HPC - hippocampus. Right side: Percentage inhibition of ${ }^{3} \mathrm{H}$-diprenorphine binding in foetal male and female (day 110 ) hypothalamus using specific ligands of $\mu$ - (DAGO); $\delta$ - (DPPE) and K- (u-69593) opioid receptor types.

Other than the possible critical involvement of cannabinoid receptors in survival of the newborn (Fride, 2002), nothing is known about the effects of endocannabinoids in the foetal pig. Cannabinoids are compounds found in marijuana. The first endogenous cannabinoid ligand, 'endocannabinoid', was isolated from the pig brain in 1992 (for review see Fride, 2002) and named anandamide (arachidonoyl ethanol amide). This lipid neurotransmitter binds to the three cannabinoid receptor subtypes CB1, CB2 and CB1A. A general inhibitory action of anandamide on LH secretion was described by de Miguel et al. (1998) and Wenger et al. (2001).

\section{Cytokines}

Among the regulatory mechanisms of $\mathrm{LH}$ secretion, cytokines and nitric oxide (NO) are still newcomers. Although a body of evidence illustrates the predominantly excitatory role of NO 

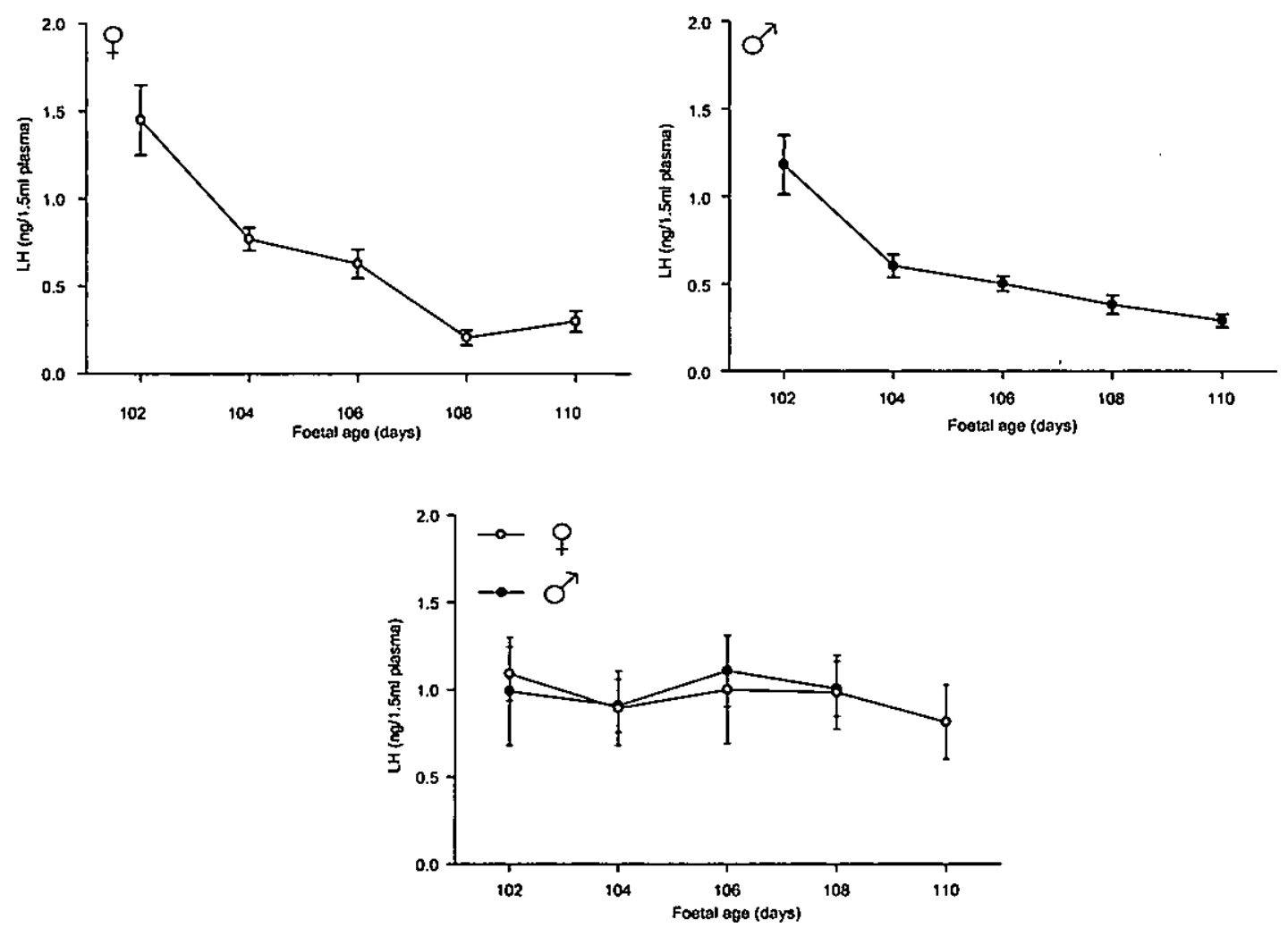

Figure 8. Plasma LH concentrations in foetal pigs receiving daily injections of morphine $(0.1 \mathrm{mg} / \mathrm{kg}$, left panel), naloxone $(0.1 \mathrm{mg} / \mathrm{kg}$; right panel) or morphine + naloxone (lower panel).

in regulation of LH secretion (McCann et al., 2001; Gouveiaand Fronci, 2004; Moreno and Franci, 2004) and LH action (Nishida et al., 2000), there are no data supporting the role of NO in the ontogeny of L.H secretion. Cytokines have been postulated to be mediators of immuno-endocrine interactions (Besedovsky and Rey, 1996), but the significance of cytokines in development, maturation and function of the hypothalamo-pituitary system has yet to be established. In general, interleukins, particularly interleukin-1 ß, inhibit LH release (Kalraet al., 1990; Bonavera et al., 1994). There has also been an occasional report that interleukin-1 stimulated LH secretion. Our studies showed that both iv administration and microinjections of human recombinant interleukin-1 B into the hypothalamic area of foetal pigs induced a sexually dimorphic response. Such microinjections caused a rapid rise in plasma LH levels in 103 to 107 day-old female foetuses, while male foetuses remained unaffected. It is noteworthy that a close relationship between opioids and interleukins exists at different levels. Interleukin-1 and interleukin-2 bind to brain opioid receptors (Jiang et al., 1995). Furthermore, interleukins stimulated opioid production in the brain. Both opioids and interleukins are highly active during situations of so-called tissue stress, such as phases of rapid growth. Whether these two systems interact to regulate neuronal growth is not yet known.

In conclusion, development of the "regulatory phenotype" of pituitary LH secretion commences around day $30 \mathrm{pc}$ and continues throughout pregnancy. Hypothalamic control mechanisms are fully functioning before birth. In contrast, little is known about the development of 
extrahypothalamic mechanisms. Consequences of malfunction of steroids during foetal ontogeny are well documented. On the other hand, not much information is available concerning foetal development of such systems as opioids, catecholamines, cytokines etc. which are regarded as secondary regulatory systems.

\section{Acknowledgement}

The work was partly supported by grants from "Deutsche 'Forschungsgemeinschaft", DFG to NP.

\section{References}

Aikawa S, Kato $T$, Elsaesser F and Kato Y (2003) Molecular cloning of porcine neuronatin and analysis of its expression during pituitary ontogeny Exp Clin Endocrinol Diab 111475-479

Bayon A, Shoemaker WI, Bloom FE, Mauss A and Guillemin R (1979) Perinatal development of the endorphin- and enkephalin-containing system in the rat brain Brain Res 179 93-101

Behrens-Herrler and Parvizi N (1993) Long-term treatments with morphine and naloxone have sex-differentiated effects on luteinizing hormone secretion in chronically catheterised foetal pigs J Neuroendocrinol 4113-118

Besedovsky HO, and Rey AD (1996) Immune-endocrine interaction: facts and hypothesis Endocr Rev 17 34-102

Bonavera IJ, Sahu A, Kalra SP and Kalra PS (1994) The hypothalamic peptides, $\alpha$-endorphin, neuropeptide $K$ and interleukin-1 $\alpha$, and the opiate morphine, enhance the excitatory amino acid-induced LH release under the influence of gonadal steroids Neuroendocrinology 6 557-564

Bruhn T, Parvizi N and Ellendorff F (1983) Ontogeny of hypothalamus-pituitary function in the foetal pig: gonadotropin release in response to electrical and electrochemical stimulation of the hypothalamus Endocrinology 112 639-644

Cicero TJ, Adams ML, O= Connor LH and Nock B (1989) In vivo evidence for a direct effect of naloxone on testicular steroidogenesis in the male rat Endocrinology $125957-963$

Colenbrander B,Kruip TAM, Dieleman SJ and Wensing CJG (1977) Changes in serum LH concentrations during normal and abnormal sexual development in the pig Biol Reprod 17 506-513

Colenbrander B, Macdonald AA, Elsaesser F, ParviziN and van de Wiel DFM (1982) Response of luteinizing hormone and follicle-stimulating hormone to luteinizing hormone releasing hormone in the foetal pig Biol Reprod 27 556-561

Conley AJ, Rainey WE and Mason JI (1994) Ontogeny of steroidogenic enzyme expression in the porcine conceptus I Mol Endocrinol 12155-165

Dacheux F (1984) Functional differentiation of the ante- rior pituitary cells in the foetal pig: an ultrastructure immunocytochemical study Cell Tissue Res 235 623-633

Dacheux $F$ and Martinat $N$ (1983) Immunocytochemical localization of L.H, FSH and TSH in the foetal porcine pituitary Cell Tissue Res 228 277-295

Danchin E and Dubois MP (1982) Immunocytochemical study of the chronology of pituitary cytogenesis in the domestic pig (sus scrofa) with special reference to the functioning of the hypothalamo-pituitary-gonadal axis Reprod Nutr Dev 22 135-151

De Miguel R, Romero J, Munoz RM, Garcia-Gil L, Gonzalez S, Villanua MA, Makriyannis A, Ramos JA and Fernandez-Ruiz || (1998) Effects of cannabinoids on prolactin and gonadotrophin secretion: involvement of changes in hypothalamic gamma-amino butyric acid (CABA) inputs Biochem Pharmacol 15 1331-1338

Derecka K, Zhang FP, Ziecik A] and Huhtaniemil (1999) Ontogeny of $\mathrm{LH}$ receptor gene expression in the pig reproductive tract J Reprod Fertil $\mathbf{1 1 5}$ 365-372

Dingledine R, Iversen LL and Breuker $E$ (1978) Naloxone as a GABA antagonist: evidence from iontophoretic, receptor binding and convulsant studies Eur J Pharmacol47 19-27

Dou D and Joseph R (1996) Structure and organization of the human neuronatin gene Genomics33 292-297

Elsaesser $F$ andParvizi N (1979) Estrogen feedback in the pig: sexual differentiation and the effect of prenatal testosterone treatment Biol Reprod $201187-1193$

Elsaesser F, Bruhn TO and Parvizi N (1988) Ontogeny of pituitary gonadotrophin secretion in the foetal and post-natal pig in response to L.HRH in vitro J Reprod Fertil 82 71-80

Fride E (2002) Endocannabinoids in the central nervous system - an overview Prostaglandins Leukot Essent Fatty Acids $66 \quad 221-233$

Ford II, Christenson RK and Maurer RR (1980) Serum testosterone concentrations in embryonic and foetal pigs during sexual differentiation Biol Reprod 23 583-587

Gouveia EM and Franci CR (2004) Involvement of serotonin $5 \mathrm{HT}_{1}$ and $5 \mathrm{HT}_{2}$ receptors and nitric oxide 
synthase in the medial preoptic area on gonadotropin secretion Brain Res Bull 63 243-251

Goxe B, Prunier A, Remy II and Salesse R (1993) Ontogeny of gonadal luteinizing hormone and follicle-stimulating hormone receptors in the foetal pig and related changes in gonadotropin and testosterone secretion Biol Reprod 49609-616

Granz S, Ellendorff F, Grossmann R, Kato Y, Mühlbauer $E$ and Elsaesser $F$ (1997) Ontogeny of growth hormone and LH beta-, FSH beta- and alpha-subunit mRNA levels in the porcine foetal and neonatal anterior pituitary I Neuroendocrinol9 439-449

Grevel J, Victor $Y$ and Sadee W (1985) Characterization of a labile naloxone binding site ( $X$ site) in rat brain ) Neurochem 44 1647-1656

Hauser KF, McLaughlin PJ and Zagon IS (1989) Endogenous opioid system and the regulation of dendritic growth and spine formation I Comp Neurol 281113

Jiang CL, Lu CL and Liu XY (1995) Multiple actions of cytokines on the CNS. Trends Neurosci 18296

Joseph R, Dou D and Tsang W (1994) Molecular cloning of a novel mRNA (neuronatin) that is highly expressed in neonatal mammalian brain Biochem Biophys Res Commun 201 1227-1234

Joseph R, Dou D and Tsang W (1995) Neuronatin mRNA: alternatively spliced forms of a novel brain-specific mammalian developmental gene Brain Res 690 92-98

Kahle H (1993)Studien zum Opioidsystem beim Schwein [Study of opioid system in the pig] Dissertation University of Göttingen, Landbauforschung Völkenrode, Sonderheft 139, pp 1-115

Kalra PS, Sahu A and Kalra SP (1990) Interleukin-1 inhibits the ovarian steroid-induced luteinizing hormone surge and release of hypothalamic luteinizing hormone-releasing hormone Endocrinology 126 2145-2152

Kent J, Pert CB and Herkenham M (1982) Ontogeny of opiate receptors in rat forebrain: visualization by in vitro autoradiography Dev Brain Res 2 487-504

Kineman RD, Kraeling RR, Crim JW, Leshin LS, Barb CR and Rampacek GB (1989) Localization of proopiomelanocortin (POMC) immunoreactive neurons in the forebrain of the pig Biol Reprod $\mathbf{4 0}$ 1119-1126

Ma E, Milewki N, Grossmann R, Ivell R, Kato $Y$ and Ellendorff $F$ (1994) Proopiomelanocortin gene expression during pig pituitary and brain development J Neuroendocrinol6 201-209

Ma E, Klempt $N$, Grossmann $R$, Ivell $r$, Kato $Y$ and Ellendorff $F$ (1996) Expression of $\mathrm{GH}, \mathrm{TSH}$ beta , $\mathrm{LH}$ beta and FSH beta genes during foetal pituitary development in the pig Exp Clin Endocrinol Diab 104 464-472

McCann SM, Karanth S, Mastronardi CA, Dees WL, Childs G, Miller B, Sower S and Yu WH (2001) Control of gonadotropin secretion by follicle-stimulating hormone-releasing factor, luteinizing hormone-releasing hormone, and leptin Arch Med Res 32 476-485

Meijer JC, Colenbrander B, Poot P and Wensing CJG
(1985) Development of pituitary gonadotropic cells in the pig fetus and the effect of luteinizing hormone-releasing hormone administration Biol Reprod 32 137-143

Moreno AS and Franci CR (2004) Estrogen modulates the action of nitric oxide in the medial preoptic area on luteinizing hormone and prolactin secretion Life Sci 74 2049-2059

Nishida N, Hattori MA, Takesue $K$, Kato $Y$ and Fujihara $N(2000)$ Critical role of nitric oxide in expression of porcine L.H receptor at transcription and post-transcription levels Exp Clin Endocrinol Diabetes $108 \quad 424-429$

Paden CM, McEwen BS, Fishman I, Snyder L and deGroff $V$ (1982) Competition by estrogens for catecholamine receptor binding in vitro I Neurochemistry 39 $512-520$

Parvizi N (1986) Differential effects of catecholoestradiol-17ß and oestradiol-17ß on concentrations of plasma LH in the foetal pig I Endocrinol111 297-300

Parvizi $N$ and Ellendorff $F$ (1975) 2-Hydroxyoestradiol-17B as a possible link in steroid brain interactions Nature 256 59-60

Parvizi $N$ and Ellendorff $F(1980)$ Beta-endorphin alters luteinizing hormone secretion via the amygdala but not the hypothalamus Nature $286812-813$

Parvizi $N$ and Ellendorff $F$ (1983) Catecholestrogens in the brain: Neuroendocrine integration I Steroid Biochemistry 19 615-618

Petric N, Kato $Y$ and Elsaesser F (2004) Infiluence of prenatal testosterone treatment of foetal and prepubertal LH-B subunit mRNA and plasma $\mathrm{LH}$ concentrations in the female pig Dom Anim Endocrinol 27 25-38

Pittius CW, Ellendorff F, Höllt V and Parvizi N (1987) Ontogenetic development of proenkephalin $A$ and proenkephalin 8 messenger RNA in foetal pigs Exp Brain Res 69208-212

Ponzilius KH, Parvizi N, Elsaesser $F$ and Ellendorff $F$ (1986) Ontogeny of secretory patterns of LH release and effects of gonadectomy in the chronically catheterised pig fetus and neonate Biol Reprod $\mathbf{3 4}$ 602-612

Raeside JI and Middleton AT (1979) Development of testosterone secretion in the foetal pig testis Biol Reprod 21 985-989

Rasmussen DD, Kennedy BP, Ziegler MG and Nett TM (1988) Endogenous opioid inhibition and facilitation of gonadotropin-releasing hormone release from the median eminence in vitro: potential role of catecholamines Endocrinology 123 2916-2921

Sasaki F, IchikawaY and Yamauchi S (1992) Immunohistological analysis in the distribution of cells in the foetal porcine adenohypophysis Anat Rec 233135-142

Sornson MW, Wu W, Dasen IS, Flynn Se, Norman DI, O'Connell SM, Gukovsky I, Carriere C, Ryan AK, Miller AP, Zuo L, Gleiberman AS, Andersen B, Beamer WG and Rosenfeld MG (1996) Pituitary lineage determination by the Prophet of pit-1 homeodomain factor 
defective in Ames dwarfism Nature 384 327-333

Taylor CC, Wu D, SoongY Yee JS and Szeto HH (1996) Differential mechanisms of ovine foetal pituitary stimulation by a selective kappa-opioid agonist and by dynorphin Neuroendocrinology 64 419-424

Usui H, Morii K, Tanaka R, Tamura T, Washiyama K, Ichikawa T, and Kumanishi T (1997) CDNA cloning and mRNA expression analysis of the human neuronatin. High level expression in human pituitary gland and pituitary adenomas J Mol Neurosci 955-60

Visser JH and Heyns CF (1996) Luteinizing hormone, follicle-stimulating hormone, testosterone and dihydrotestosterone during testicular descent in the pig fetus Reprod Fertil Dev 8 1115-1120

Wenger T, Ledent C, Csernus V and Gerendai I (2001) The central cannabinoidreceptor inactivation sup- presses endocrine reproductive functions Biochem Biophys Res Commun 8 363-368

Wijnholds J, Chowdhury K, Wehr R and Gruss P (1995) Segment-specific expression of the neuronatin gene during early hindbrain development Dev Biol 171 73-84

Yang KP and Challis JR (1991) Opioid receptors are present in the hypothalamus but not detectable in the anterior pituitary of the developing ovine fetus Neuroendocrinology 53 623-627

Zeng J, Aldag P and Elsaesser F (2005) Signal Transduction mediating gene expression of SP1, LH- $B$ subunit and $\mathrm{GH}$ in response to $\mathrm{GnRH}$ or GHRH in the postnatal and foetal porcine anterior pituitary in vitro Exp Clin Endocrinol Diab 11321-30 